\title{
"The potential financial impact and influence of black economic empowerment (BEE) on private higher education institutions in South Africa: management alert"
}

\begin{tabular}{|c|c|}
\hline AUTHORS & $\begin{array}{l}\text { Riaan Dirkse van Schalkwyk (D https://orcid.org/0000-0001-8511-5648 } \\
\text { Louis P. Krüger (D https://orcid.org/0000-0003-3632-427X }\end{array}$ \\
\hline ARTICLE INFO & $\begin{array}{l}\text { Riaan Dirkse van Schalkwyk and Louis P. Krüger (2019). The potential financial } \\
\text { impact and influence of black economic empowerment (BEE) on private higher } \\
\text { education institutions in South Africa: management alert. Problems and } \\
\text { Perspectives in Management, 17(3), 45-56. doi:10.21511/ppm.17(3).2019.04 }\end{array}$ \\
\hline DOI & http://dx.doi.org/10.21511/ppm.17(3).2019.04 \\
\hline RELEASED ON & Thursday, 25 July 2019 \\
\hline RECEIVED ON & Wednesday, 05 September 2018 \\
\hline ACCEPTED ON & Tuesday, 21 May 2019 \\
\hline LICENSE & $\begin{array}{l}(c) E Y \\
\text { This work is licensed under a Creative Commons Attribution } 4.0 \text { International } \\
\text { License }\end{array}$ \\
\hline JOURNAL & "Problems and Perspectives in Management" \\
\hline ISSN PRINT & $1727-7051$ \\
\hline ISSN ONLINE & $1810-5467$ \\
\hline PUBLISHER & LLC "Consulting Publishing Company "Business Perspectives" \\
\hline FOUNDER & LLC "Consulting Publishing Company "Business Perspectives" \\
\hline
\end{tabular}

NUMBER OF REFERENCES

25

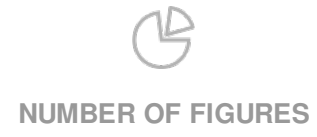

1
NUMBER OF TABLES

4

(C) The author(s) 2021. This publication is an open access article. 


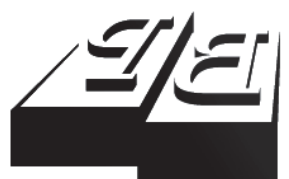

BUSINESS PERSPECTIVES

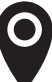

LLC "CPC "Business Perspectives" Hryhorii Skovoroda lane, 10, Sumy, 40022, Ukraine

www.businessperspectives.org

Received on: $5^{\text {th }}$ of September, 2018 Accepted on: $21^{\text {st }}$ of May, 2019

(C) Riaan Dirkse van Schalkwyk, Louis P. Krüger, 2019

Riaan Dirkse van Schalkwyk, Ph.D., Senior lecturer of Operations Management, College of Economic and Management Sciences, Department of Operations Management, University of South Africa, South Africa.

Louis P. Krüger, DBA, Professor of Operations Management, College of Economic and Management Sciences, Department of Operations Management, University of South Africa, South Africa.

\section{(ㄷ)(i)}

This is an Open Access article, distributed under the terms of the Creative Commons Attribution 4.0 International license, which permits unrestricted re-use, distribution, and reproduction in any medium, provided the original work is properly cited.

\section{THE POTENTIAL FINANCIAL IMPACT AND INFLUENCE OF BLACK ECONOMIC EMPOWERMENT (BEE) ON PRIVATE HIGHER EDUCATION INSTITUTIONS IN SOUTH AFRICA: MANAGEMENT ALERT}

\begin{abstract}
Education is considered an important pillar of economic development and a vital factor for nation building in post-1994 South Africa. Higher education (HE) is offered by government-subsidized universities and colleges, while there has been an increase in the number of private higher education institutions (PHEIs), which offer more expensive, unsubsidized tertiary education. While all state bodies and public entities are required to apply the provisions of the Broad-Based Black Economic Empowerment (B-BBEE) Act, this is not (yet) seemingly a requirement for PHEIs. This study used an adapted version of the " 5 Star" research methodology to explore the potential financial impact and influence of the African National Congress's (ANC's) black economic empowerment (BEE) policy on PHEIs. The research shows that the BEE policy has the potential to financially impact and influence most of the components of the total quality service (TQS) framework for PHEIs in terms of preferential procurement from suppliers, company ownership, appointment of executive, middle and junior managers, employment of academic and administrative staff, and throughput of black student graduates. Management at PHEIs should be alerted to the fact that it is probably not merely a matter of IF, but rather WHEN the policy will start impacting on the financial stability and viability of PHEIs as BEE compliance becomes mandatory.
\end{abstract}

\section{Keywords}

black economic empowerment (BEE), broad-based black economic empowerment (B-BBEE), African National Congress (ANC), private higher education institutions (PHEIs)

JEL Classification M14, M21

\section{INTRODUCTION}

The late former President of South Africa, Nelson Rolihlahla Mandela, who was arguably one of the greatest and most-revered leaders the world has yet seen, is quoted to have said "Education is the most powerful weapon which you can use to change the world". He later elaborated on the importance of education as a nation builder by stating the following: "The power of education extends beyond the development of skills we need for economic success. It can contribute to nation-building and reconciliation. Our previous system emphasized the physical and other differences of South Africans with devastating effects. We are steadily but surely introducing education that enables our children to exploit their similarities and common goals, while appreciating the strength in their diversity" (Washington Post, 2013).

Broad-based black economic empowerment (B-BBEE), hereafter simply referred to as black economic empowerment (BEE), was first legis- 
lated by the ruling ANC party in South Africa in 2003 under the presidency of Thabo Mbeki (Prominent People, 2013). BEE is basically a race-based formula that prescribes preference for so-called "black people" (which includes South Africans, Indians, coloreds, Chinese and others), but explicitly excludes white people (Krüger, 2018).

In South Africa today, unfortunately some of the more negative influences of BEE are clearly visible. They are the instances of corruption, cheating, fraud, looting, perjury, patronage, misrepresentation, nepotism and self-enrichment, to name but a few. The ANC's BEE policy has influenced all levels of government, as well as businesses/enterprises, since its inception in 2003 and has provided the impetus and fertile soil for these nefarious symptoms to flourish, resulting in what has become known as state capture.

This article reports the findings of an exploratory qualitative and predictive research study that used a " 5 Star" research methodology (adapted) to investigate the potential financial impact and influence that the ANC's BEE policy could have on private higher education institutions (PHEIs) in South Africa. The research involved the use of a total quality service (TQS) framework that was specifically developed for PHEIs in earlier research, on which the BEE scorecard elements were superimposed in order to determine the possible financial impact and influence of BEE compliance should it become a mandatory requirement in the future.

\section{THEORETICAL BASIS}

\subsection{BEE research and legislation}

The research on BEE in South Africa by one of the authors of this article has been ongoing since 2011, and the findings have been published in six journal articles thus far. In the last article, he investigated the impact and influence of the ANC's BEE policy on six macro "PESTIS": political, economic, social, technological, institutional and structural environments (Krüger, 2018). That research confirmed that in at least four of the abovementioned macro-environments, BEE policy has had a definite and profound negative influence. One of these four environments was the institutional macro-environment, which features education and includes both primary and secondary schools, as well as tertiary universities in the public sector, and PHEIs in the private sector on which this article is based.

BEE was first legislated under Act 53 of 2003 in South Africa. This Act and the B-BBEE Amendment Act 46 of 2013 provide the legislative framework for the promotion of BEE and empower the Minister of Trade and Industry to administer all the provisions of the Acts in order to advance economic transformation and enhance economic participation of black people in the South African economy (see DTI, 2016).
According to the B-BBEE Amendment Act, 'black people' is a generic term, which means Africans, coloreds and Indians:

1. who are citizens of the Republic of South Africa by birth or descent; or

2. who became citizens of the Republic of South Africa by naturalization:

a) before April 27, 1994;

b) on or after April 27, 1994 and who would have been entitled to acquire citizenship by naturalization prior to that date; and 'broad-based black economic empowerment' means the viable economic empowerment of all black people, in particular women, workers, youth, people with disabilities and people living in rural areas through diverse but integrated socio-economic strategies that include but not limited to:

- increasing the number of black people who manage, own and control enterprises and productive assets;

- facilitating ownership and management of enterprises and productive assets by communities, workers, cooperatives and other collective enterprises; 
- human resource and skills development;

- achieving equitable representation in all occupational categories and levels in the workforce;

- preferential procurement from enterprises that are owned or managed by black people; and

- investment in enterprises that are owned or managed by black people.

The objectives of BEE, according to two abovementioned Acts, are to "... facilitate broad-based black economic empowerment limited by:

1. promoting economic transformation in order to enable meaningful participation of black people in the economy;

2. achieving substantial change in the racial composition of ownership and management structures and in the skilled occupation of existing and new enterprises;

3. increasing the extent to which communities, workers, cooperatives and other collective enterprises own and manage the existing and new enterprises and increasing their access to economic activities, infrastructure and skills training;

4. increasing the extent to which black women own and manage the existing and new enterprises, and increasing their access to economic activities, infrastructure and skills training;

5. promoting investment programs that lead to broad-based and meaningful participation in the economy by black people in order to achieve sustainable development and general prosperity;

6. empowering rural and local communities by enabling access to economic activities, land, infrastructure, ownership and skills;

7. promoting access to finance for black startups, small, medium and micro enterprises, co-operatives and black entrepreneurs, including those in the informal business sector;
8. increasing effective economic participation and black owned and managed enterprises, including small, medium and micro enterprises and co-operatives and enhancing their access to financial and non-financial support" (Act 53 of 2003 and the B-BBEE Amendment Act 46 of 2013).

\subsection{BEE application}

According to the B-BBEE Amendment Act, "Every state body and public entity must apply any relevant code of good practice issued in terms of this Act in:

1. determining qualification criteria for the issuing of licences, concessions or other authorizations in terms of any law;

2. developing and implementing a preferential procurement policy;

3. determining qualification criteria for the sale of state-owned enterprises;

4. developing criteria for entering into partnerships with the private sector;

5. determining criteria for the awarding of incentives, grants and investment schemes in support of broad-based black economic empowerment".

In terms of the B-BBEE Amendment Act, the government's strategy for B-BBEE applies to “... all state bodies, public entities, the private sector, non-governmental organizations, local communities and other stakeholders". Private companies or enterprises are considered in three categories, namely exempted micro-enterprises (EME) (turnover threshold $<$ R 10 million), qualifying small enterprises (QSE) (turnover threshold $>$ R 10 but $<\mathrm{R} 50$ million) and large entities (turnover threshold > R 50 million) (DTI, 2012).

\subsection{BEE scorecard}

The revised BEE scorecard by which all enterprises are measured for their level of compliance is prescribed by the Department of Trade and Industry (DTI). They have formulated three principal broad- 
based policy objectives (DTI, 2012). The first policy encompasses direct empowerment, which comprises two components, namely black ownership (weighting 25 out of 105 points) and management control (weighting 15 out of 105 points). The second policy encompasses human resources empowerment (20 points of 105), which comprises two components, namely employment equity and skills development (weighting 20 out of 105 points). The third and last policy encompasses indirect empowerment. This comprises three components, the first two, which entail preferential procurement and enterprise development (weighting 40 out of 105 points), and the last socio-economic development (weighting 5 out of 105 points).

\subsection{BEE compliance}

The B-BBEE Amendment Act makes provision for the Minister of Trade and Industry to issue sector (industry) codes of good practice by which an enterprise in that particular sector should be measured for compliance with the requirements of BEE, and such an enterprise must report its compliance annually. However, in the absence of industry- or sector-specific codes of good practice, a generic scorecard as is discussed below will be applicable and provides the B-BBEE status, the qualification points and the B-BBEE recognition level that is awarded to an enterprise based on its compliance with BEE targets (DTI, 2012):

- level 1 - qualification points $\geq 100$ points (very good level of acceptance) with B-BBEE recognition level of 135\%;

- level 2 - qualification points $\geq 95$, but $<100$ points (very good level of acceptance) with B-BBEE recognition level of $125 \%$;

- level 3 - qualification points $\geq 90$, but $<95$ points (good level of acceptance) with B-BBEE recognition level of $110 \%$;

- level 4 - qualification points $\geq 80$, but $<90$ points (good level of acceptance) with B-BBEE recognition level of $100 \%$;

- level 5 - qualification points $\geq 75$, but $<80$ points (moderate level of acceptance) with B-BBEE recognition level of $80 \%$; level 6 - qualification points $\geq 70$, but $<75$ points (moderate level of acceptance) with B-BBEE recognition level of $60 \%$;

evel 7 - qualification points $\geq 55$, but $<70$ points (minimum level of acceptance) with B-BBEE recognition level of 50\%;

- $\quad$ level 8 - qualification points $\geq 40$, but $<55$ points (minimum level of acceptance) with B-BBEE recognition level of $10 \%$;

- non-compliant - qualification points $<40$ points (unacceptable level of acceptance) with $\mathrm{B}$-BBEE recognition level of $0 \%$.

The objective of the research on which this article was based was to investigate the potential financial impact and influence of the ANC's BEE policy on PHEIs in South Africa. The sections that follow set the scene for the inductive research process by providing a brief summary of the higher education environment in South Africa, followed by an overview of a proposed qualitative TQS framework for PHEIs.

\subsection{The higher education (HE) landscape in South Africa}

In 2015, the public HE landscape in South Africa consisted of 26 public institutions. These comprised eleven traditional academic universities, nine comprehensive universities (offering both academic and vocational training) and six dedicated universities of technology (mainly vocational training), with a total student enrolment of 985,212 students (Department of Higher Education and Training, 2017a). This total represented $87 \%$ of the total HE student population in the country with the remaining $13 \%$ being accommodated in PHEIs. According to the abovementioned report, the majority of HE students in the country, namely 604,480 , were enrolled in the traditional contact or classroom lecturer-student mode of learning, while 379,732 students were registered for distance education or non-direct contact learning, including the online blended mode. After 1994, policy development in South African HE was initiated by the National Commission on Higher Education (NCHE), with its primary purpose of creating a policy for the transformation of 
Table 1. Number of available first-year enrollments and number of applications received at five selected HE institutions in 2015

Source: Summarized by the authors from Nel (2015) and Marais (2014).

\begin{tabular}{|c|c|c|}
\hline University & Number of available first-year enrollments & Number of first-year applications \\
\hline University of Johannesburg & 10,500 & 111,200 \\
\hline University of Pretoria & 10,250 & $+42,000$ \\
\hline University of the Witwatersrand & 6,250 & $+51,000$ \\
\hline University of Stellenbosch & 5,000 & 22,500 \\
\hline University of the Western Cape & 4,000 & 25,800 \\
\hline Total & 36,000 & 252,500 \\
\hline
\end{tabular}

South Africa's HE sector. This process eventually led to the proclamation of the Higher Education Act 101 of 1997.

HE in South Africa is highly regulated, and almost all plans formulated and decisions made are according to policy directives. All HE programs must be registered with the South African Qualifications Authority (SAQA), accredited by the Higher Education Quality Committee (HEQC) and approved by the Department of Higher Education and Training (DHET).

While there are many challenges in the HE landscape in South Africa such as declining government subsidies and outstanding student fees, which lead to a shortage of funding (Fourie, 2009), another major challenge that exacerbates the situation is the physical lack of positions or space available for enrollment of prospective learners. It is highly unlikely that this situation will change soon, and public universities will continue to only enroll only a fraction of those who apply (Vega School, 2017). The huge discrepancy described above, is partly illustrated in Table 1, which provides a comparison of the available number of enrollments for first-year students at five of the larger public universities and the number of first-year applicants, which is more than $85 \%$ of students being turned away. In other words, only $15 \%$ of those first-year students who applied could actually be enrolled in 2015 .

Fourie (2009) identifies the following three characteristics that differentiate public universities from other private organizations. Firstly, the mission and goals of universities are often vague and although they are traditionally non-profit organizations, they have been "forced" to become more entrepreneurial in recent years. Secondly, public universities are systems that are loosely joined with different divisions (colleges), but which have weak links between them as part of the larger organization. Thirdly public universities, which are sometimes referred to as "professional bureaucracies", are characterized by academics who largely conduct their teaching and research independently and usually have a stronger commitment to their field of expertise than to the university itself.

\subsection{The PHEl landscape in South Africa}

In contrast to the public HE sector, most PHEIs in South Africa are business oriented and profit driven. They serve a relatively small number of students, that is, fewer than 150,000 , of which the majority are female, compared to a total HE student population in South Africa of around one million students in 2015 (see Table 2). However, the number of PHEIs is 125 compared to only 26 public universities - almost five PHEIs for each one public university. Most of the PHEIs in South Africa follow the same trend as in other countries with almost $50 \%$ of all enrolments in the commerce and management fields (Levy, 2002).

The number of students enrolled in PHEIs by each South African population grouping and foreign students is provided in Table 3. The majority of students for the time period from 2010 to 2015 were black South Africans around 56\%, followed by white students at $20 \%$, coloreds at $8 \%$, and Indians at 6\%. Foreign or non-South African students make up approximately $10 \%$ of total PHEI enrolment.

It should be kept in mind that because PHEIs are profit driven, they must be able to respond rapidly to market forces and the demand for high-quality service and education, because their "custom- 
Table 2. Number of students enrolled in PHEls by gender from 2010 to 2015

Source: Summarized by the authors from the Department of Higher Education and Training (2017a, p. 20) and Department of Higher Education and Training (2017b, p. 25).

\begin{tabular}{c|c|c|c|c}
\hline Year & Male & Female & Unspecified & Total \\
\hline 2010 & $44,121(48 \%)$ & $46,646(52 \%)$ & $n / a$ & $90,767(100 \%)$ \\
\hline 2011 & $48,876(47 \%)$ & $54,160(53 \%)$ & $n / a$ & $103,036(100 \%)$ \\
2012 & $43,704(49 \%)$ & $53,774(51 \%)$ & $n / a$ & $97,478(100 \%)$ \\
\hline 2013 & $55,606(46 \%)$ & $64,335(54 \%)$ & $n$ & $119,941(100 \%)$ \\
\hline 2014 & $65,431(46 \%)$ & $73,776(52 \%)$ & $142,557(100 \%)$ \\
2015 & $66,503(45.2 \%)$ & $80,487(54.7 \%)$ & $163(0.1 \%)$ & $147,153(100 \%)$ \\
\hline
\end{tabular}

Table 3. The number of students enrolled in PHEls by South African population group and nationality from 2010 to 2015

Source: Summarized by the authors from the Department of Higher Education and Training (2017a, p. 20) and the Department of Higher Education and Training (2017b, p. 25).

\begin{tabular}{|c|c|c|c|c|c|c|c|}
\hline Year & Black & Colored & Indian/Asian & White & $\begin{array}{c}\text { Total number } \\
\text { of South } \\
\text { African } \\
\text { students }\end{array}$ & $\begin{array}{c}\text { Non-South } \\
\text { African } \\
\text { students } \\
\text { (unspecified) }\end{array}$ & $\begin{array}{c}\text { Total number } \\
\text { of students }\end{array}$ \\
\hline 2010 & $51,720(57 \%)$ & $7,516(8 \%)$ & $5,644(6 \%)$ & $18,334(20 \%)$ & $83,214(92 \%)$ & $7,553(8 \%)$ & 90,767 (100\%) \\
\hline 2011 & $56,988(55 \%)$ & $7,526(7 \%)$ & $5,913(6 \%)$ & $23,311(23 \%)$ & $93,738(91 \%)$ & $9,298(9 \%)$ & $103,036(100 \%)$ \\
\hline 2012 & $56,813(58 \%)$ & $6,876(8 \%)$ & $5,222(5 \%)$ & $18,500(19 \%)$ & $87,411(90 \%)$ & $10,067(10 \%)$ & $97,478(100 \%)$ \\
\hline 2013 & $64,933(54 \%)$ & $8,183(7 \%)$ & $6,649(6 \%)$ & $26,664(22 \%)$ & $106,429(89 \%)$ & $13,512(11 \%)$ & $119,941(100 \%)$ \\
\hline 2014 & $80,983(57 \%)$ & $12,716(9 \%)$ & $10,396(8 \%)$ & $22,191(15 \%)$ & $126,286(89 \%)$ & $16,271(11 \%)$ & $142,557(100 \%)$ \\
\hline 2015 & $83,968(57 \%)$ & $11,120(8 \%)$ & $9,449(6 \%)$ & $25,726(18 \%)$ & $130,263(88 \%)$ & $16,890(12 \%)$ & $147,153(100 \%)$ \\
\hline
\end{tabular}

ers" pay a premium as compared to public sector students... Their customer service orientation and survival in a highly competitive market, where there are many providers "chasing" a few "customers", require a special emphasis and approach such as the adoption of a total quality service (TQS) framework, which is described in the next subsection.

\subsection{A TQS framework for PHEls: a qualitative perspective}

Research conducted by Dirkse van Schalkwyk and Steenkamp (2016) found that in the organizations in service industries, service quality is the single qualifier or disqualifier for continued sustainability. PHEIs in South Africa are no exception. The growing number of registered PHEIs is a clear indication of the increasing demand for private education, although this trend is accompanied by the need for government regulation and sound corporate governance. Sustainable service quality is thus a requirement both in terms of government involvement and for the business sustainability of PHEIs. Their research culminated in the development of the first TQS framework for PHEIs in South Africa.
The researchers followed a qualitative approach by identifying TQS dimensions from a PHEI's top management perspective to create a TQS framework. The research process commenced with an extensive literature study focusing on TQS and service quality frameworks, models and dimensions incorporating 29 industries in 26 countries over the preceding 25 years. Following the literature study, a concept interview guide was developed. The researchers then set about validating the interview guide. During the validation process, the guide was adapted by experts in quality management and through further qualitative research. The cooperation of six prominent South African PHEIs (with 13 campuses across South Africa and Namibia), which offer degree qualifications, was elicited for participation in the research. Interviews were then conducted with 15 principals (CEOs or top managers) of the PHEIs. The data analysis and data reduction process by means of descriptive open coding and thematic analysis produced several service quality dimensions and overarching themes from a top management perspective. For the purposes of this article, it is the five-process components of the TQS framework that are aligned with the seven BEE scorecard elements (see Figure 1). 


\section{A TOS FRAMEWORK WITH BEE SCORECARD ELEMENTS}

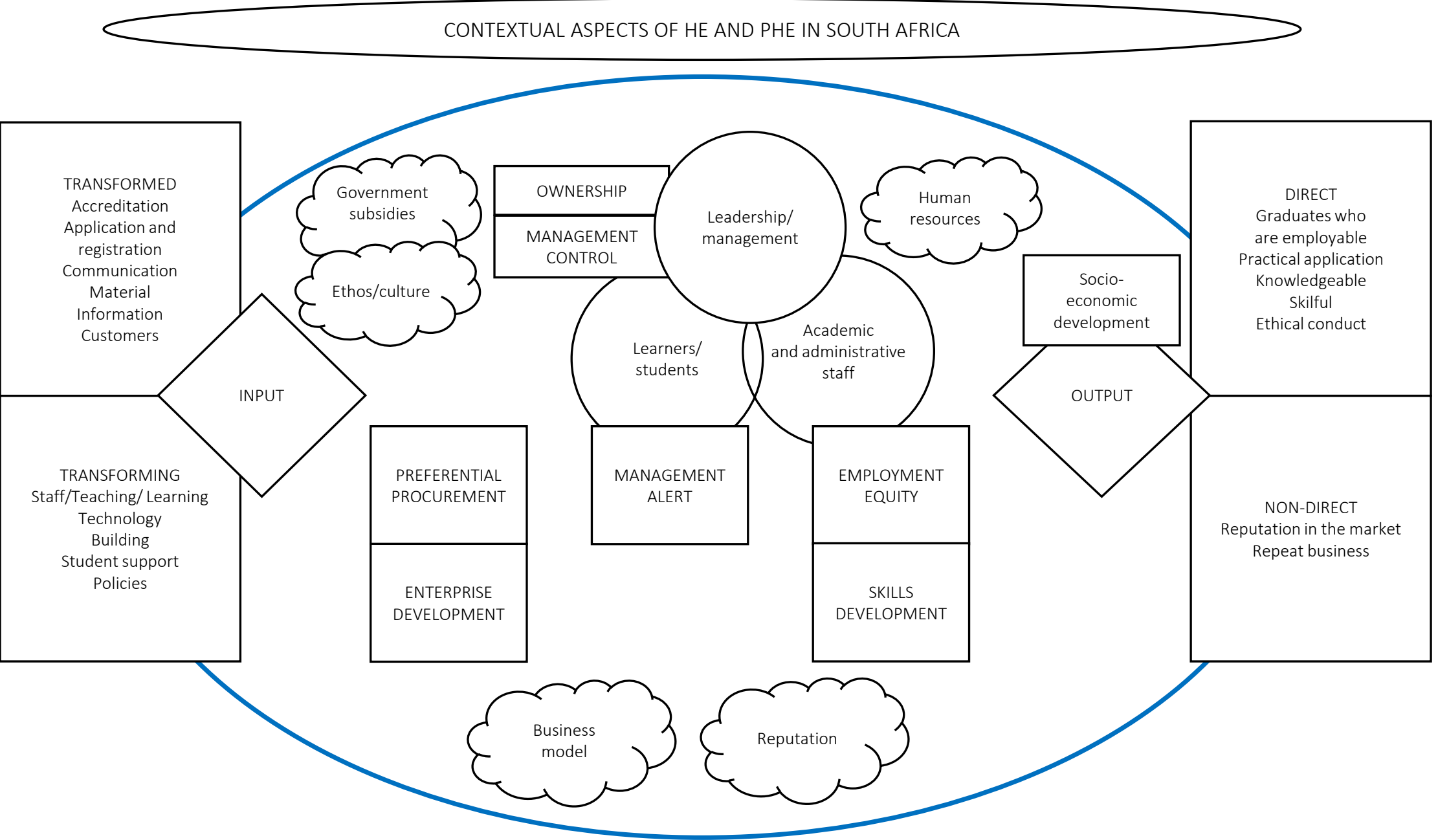




\section{METHODS}

The following section is mainly based on the research methodology adopted by Krüger (2018) and also utilized in further research into BEE by the mentioned author in 2016 and 2018.

The research on which this article was based falls within the interpretivist/constructivist paradigm (or theoretical framework). This type of approach in research attempts "... to understand the subjective world of human experience" (Cohen, Manion, \& Morrison, 2005, p. 22). Acknowledging the particular paradigm as the first step, it subsequently “... sets down the intent, motivation and expectations for the research", as well as the basis for the selection of the whole research design, including the research methodology and method(s) of research (Mackenzie \& Knipe, 2006, p. 2).

From a knowledge point of view, the research design that was used in the research had to provide a proposition of the issue, which was being researched. The "5 Star" research methodology, initially introduced by Krüger (2018), was adapted in step 3 to make provision for inductive reasoning in terms of whether a strong or weak argument and/or collection of evidence either in support of or against the proposition could be made. This was necessary because the research is predicative in nature and actual cases of the occurrence (namely compulsory BEE compliance in PHEIs) are unknown.

An inductive research approach was followed in this research study. According to Welman, Kruger, and Mitchell (2005), researchers, on occasion, enter areas where little insight or knowledge exists. In such instances, researchers proceed inductively. The phenomenon being studied should first be observed and systematically described in an attempt to identify patterns and relationships in order to develop a theory. Similarly, Leedy and Ormrod (2015, p. 387) purport that in inductive reasoning, "...a researcher begins with multiple specific observations about a particular phenomenon and then makes broader generalizations about the phenomenon".

To summarize, the "5 Star" research methodology involves five definite sequential steps, which may also be cyclical, and entail the following: step 1 - formulating a proposition; step 2 - describing the assumptions; step 3 - in this case, utilizing inductive reasoning to formulate a proposition that constitutes a possible and predictive outcome; step 4 - considering arguments both in support of or against the formulated proposition; and lastly, step 5 - drawing the conclusion. Given the above mentioned research paradigm within which the research was conducted, the knowledge outcome is considered inductive in nature and is characterized by subjective reality, exploratory, expressed in words rather than numbers, with issues being complex and broad, and lastly, rather about understanding than control (Visagie, 2013). Qualitative research is the primary method of such research where secondary data and document analysis are utilized (Mackenzie, \& Knipe, 2006) and its control measures of trustworthiness include credibility, transferability, dependability, conformability and authenticity (Visagie, 2012).

\subsection{Research proposition and assumptions}

The following subsection is based on the same assumptions made by Krüger (2018) in his research into BEE.

The basic research proposition in this study was as follows: the ANC's BEE policy could have a direct or indirect negative influence on PHEIs in South Africa should they need to become BEE compliant.

The seven assumptions underlying this research were as follows:

1. The implementation of the provisions and regulations of BEE are guided by the Broad-Based Black Economic Empowerment (B-BBEE) Act 53 of 2003, as amended by Act 46 of 2013.

2. The focus of the research was on the potential financial impact and influence that the ANC's BEE policy could have on PHEIs in South Africa should they need to become BEE complaint.

3. Most PHEIs in South Africa are registered companies and profit driven. PHEIs have to function, survive and compete in an increasingly competitive, marketing-oriented and highly regulat- 
ed environment and need to find new ways to compete if they wish to remain sustainable. The delivery of superior service quality could be the differentiating factor for success - hence the importance of a TQS framework.

4. The implementation and application of BEE policies as provided for by the B-BBEE Act, specifically target and benefit so-called "black people" who, according to the definition in the Act, include all population groups of South Africa (the majority African, as well as minority colored and Indian/Asian populations) except the socalled "white South African" minority (Krüger, 2018, pp. 365-366).

5. The meaning of the words "transform" or "transformation" in the South African context refers to the implementation and application of BEE, whether the change is to ownership, shareholding, company, business, firm, corporation, enterprise, partnership, proprietorship, title, rights, tenure, possession, control, management, supervision, jurisdiction, rule, domination, hegemony, appointment, employment, nomination, promotion, selection, choice, office, assignment, post, opening, representation, position, opinion, view, stance, standpoint, and so forth, whereby so-called "black people" must represent the majority (Krüger, 2018, p. 366).
6. Qualitative research was conducted by means of inductive reasoning and no specific empirical data was generated either through questionnaires or interviews concerning what the potential financial impact and influence of BEE compliance might be. For all practical purposes, PHEIs, some of which might voluntarily be adopting and following certain transformation targets, do not yet need to formally comply with $\mathrm{BEE}$ requirements or the BEE scorecard.

7. The guiding control measure adopted in this qualitative research included strategies of trustworthiness (including of credibility, transferability, dependability, conformability and authenticity).

\subsection{Research by means of inductive reasoning}

As noted above, the research on which this article was based was qualitative, exploratory and predictive in nature. In terms of step 3 of the above "5 Star" research methodology, no data could be gathered, because the event, namely BEE compliance by PHEIs in South Africa, has not (yet) occurred.

The alternative approach that was therefore followed in this research was to consider the various components of the TQS framework previous-

Table 4. TQS framework process component with BEE scorecard elements

Source: Developed by the authors.

\begin{tabular}{|c|c|c|c|}
\hline $\begin{array}{l}\text { TQS framework: } \\
\text { process component }\end{array}$ & $\begin{array}{l}\text { BEE scorecard } \\
\text { element }\end{array}$ & Weight & Possible influence(s) and implications \\
\hline \multirow[t]{2}{*}{ Input } & $\begin{array}{l}\text { Preferential } \\
\text { procurement }\end{array}$ & \multirow[t]{2}{*}{40} & $\begin{array}{l}\text { Procurement from suppliers must be BEE recognized with targets set } \\
>50 \% \text {. }\end{array}$ \\
\hline & Enterprise development & & Supplier businesses would need to be $51 \%$ black-owned \\
\hline \multirow{2}{*}{$\begin{array}{l}\text { Process: principal and } \\
\text { leadership }\end{array}$} & Ownership & 25 & $\begin{array}{l}\text { Black ownership of the company through shareholding would need to } \\
\text { increase to above } 50 \%\end{array}$ \\
\hline & Management control & 15 & $\begin{array}{l}\text { Black top, middle management and supervisors would need to increase } \\
\text { to comprise around } 90 \% \text { of all managers and requirements for black } \\
\text { women }\end{array}$ \\
\hline \multirow[b]{2}{*}{$\begin{array}{l}\text { Process: academic and } \\
\text { administrative staff }\end{array}$} & Employment equity & & \multirow{2}{*}{$\begin{array}{l}\text { Employment of black academic members of staff and administrative } \\
\text { personnel would need to increase to around } 90 \% \text { of all staff of the } \\
\text { institution with dedicated skills improvement programs put into place }\end{array}$} \\
\hline & Skills development & 20 & \\
\hline Process: learner & - & - & $\begin{array}{l}\text { MANAGEMENT ALERT } \\
\text { Black students who access into the institution would need to increase } \\
\text { to around } 90 \% \text { of the whole student intake in order to also increase the } \\
\text { output of black students who graduate }\end{array}$ \\
\hline Output & $\begin{array}{l}\text { Socio-economic } \\
\text { development }\end{array}$ & 5 & $\begin{array}{l}\text { The number of black students that graduate would need to increase } \\
\text { to around } 90 \% \text { of all those who complete their qualifications at the } \\
\text { institution, and funding challenges may arise as grants and bursaries } \\
\text { would probably need to be provided to cover tuition fees }\end{array}$ \\
\hline
\end{tabular}


ly developed for PHEIs in South Africa through qualitative research by Dirkse van Schalkwyk and Steenkamp (2016), and then to attempt to superimpose the elements of the BEE scorecard on the framework. The proposed superimposition of the TQS framework and the elements of the BEE scorecard are illustrated in Figure 1. Table 4 indicates the proposed alignment of the five process components of the TQS framework with the seven BEE scorecard elements.

\section{DISCUSSION OF THE RESULTS}

"BEE, which is a policy legislated by the ANC, is based purely on race. Black people are clearly defined in the B-BBEE Act 53 of 2003 (and its amendment Act 46 of 2013), and this includes all population groups of the country except so-called white people" (Krüger, 2018, p. 367).

The implementation of BEE has rather been controversial. Political commentators, authors and business leaders have been critical of BEE, because only a relatively small percentage of black people have benefitted from the policy. The well-respected researcher, Anthea Jeffery, explains the nature of BEE as follows: "This helps explain how a supposedly limited form of affirmative action has quietly morphed into a complex set of employment equity, BEE, and land reform rules that are cumulatively eroding business autonomy, undermining property rights, crippling public service efficiency, choking off direct investment, retarding economic growth and adding to a crisis of unemployment within the country". She further argues that the failures and actual outcomes fly in the face of what BEE was intended to achieve; "instead its benefits have gone mainly to a relatively small black elite, many of them well-paid but often ineffective public servants". Most alarmingly "... it [BEE] has also fostered a toxic mix of inefficiency, waste and corruption that frequently causes great harm to the 19 million poor South Africans ...", of which "... the vast majority of these truly disadvantaged individuals have little or no prospect of ever gaining management posts, ownership deals, preferential contracts, or new small business ...", and critically, “... most of them poor and unskilled, while more than 8 million of them are also unemployed" (Jeffery, 2014, pp. 2223; Krüger, 2018, p. 368).
The alignment between the TQS framework for PHEIs and the elements of the BEE scorecard illustrated in Table 4, surprisingly, was not too difficult and ended up being extremely logical, with only one component of the TQS framework seemingly not covered by any of the elements of the BEE scorecard. The TQS framework has five process elements that are arranged according to the well-known input-process-output model found in most operations management textbooks (Slack, Brandon-Jones, \& Johnston, 2013, p. 28). The first component relates to the input into the education process, that is, education providers, like other service processes such as dentists, doctors and hairdressers, amongst others, take in customers or clients to "transform" them, in this case students". The second, third and fourth process components for PHEIs involve three education conversion processes for three different role players, namely the students or learners themselves, the owners of the enterprise and managers of the business, and lastly the academic and administrative staff. The students who go through this education conversion process are "transformed" into "knowledgeable, skillful and employable" people who become the output, which is the fifth and last component of the TQS education conversion process. The seven BEE scorecard elements are preferential procurement and enterprise development, which align to the TQS framework on the input side, ownership and management control aligned to process circle II of the TQS conversion process, and employment equity and skills development aligned to process circle III on the TQS conversion process. The BEE scorecard, however, does not explicitly address process circle I of the education conversion process, namely the students or leaners who are actually to be "converted" or receive the education as such. It should be noted that it definitely would have a major impact on the TQS framework, because the majority of students that need to enroll in PHEIs would need to be black. This would be the only way to achieve a black majority throughput in graduates (BEE scorecard element of socio-economic development, which involves employability) should BEE compliance become a mandatory requirement.

The possible consequences and implications of each BEE scorecard element and points awarded for reaching certain transformation targets, 
are noted in the last column of Table 4. These are based on the generic BEE scorecard and presented for illustration purposes. It is possible that lesser or greater transformation targets and point allocations could be adopted should a sector-specific HE scorecard be applicable. Examining these possible outcomes, it should be patently clear that PHEIs would need to radically implement transformation or BEE initiatives as com- pared to their current intake of black students, preferential procurement from black suppliers, which are majority black-owned, black ownership of the PHEI, the appointment of black top, middle and junior management, the employment of a majority of black academic and administrative staff, increased attention to black skills development, and finally, a black majority throughput of graduates.

\section{CONCLUSION}

The purpose of this research was to investigate the potential financial impact and influence of the ANC's BEE policy on PHEIs in South Africa should BEE compliance become a mandatory requirement.

BEE refers to the implementation of the provisions and regulations as contained in the B-BBEE Act 53 of 2003, as amended by Act 46 of 2013. It seeks to involve more black people in the economy through various measures and scorecards, which cover a number of elements including ownership, management, employment, procurement, and skills development. PHEIs are self-funding institutions that offer tertiary education in South Africa and mainly compete with one another on the quality of their offerings and service. Generally, they are more expensive, but do offer an alternative to the limited number of positions available at government-subsidized universities.

A "5-Star" research methodology, which had previously been used in successful research projects, guided the exploratory qualitative research. The methodology was adapted to make provision for inductive reasoning to suggest outcomes, as the possible event itself, namely BEE compliance in PHEIs, has not yet occurred.

Should BEE compliance, however, become a mandatory requirement in PHEIs, the research shows that all the process components of a TQS framework that was specifically developed in earlier research for PHEIs would from a financial perspective be impacted or influenced by the elements of the BEE scorecard. In essence, BEE compliance would mean much greater black participation in all the elements mentioned above. Given the effects of the implementation of BEE in other spheres of the economy and institutions, where serious cases of corruption, cheating, fraud, looting, perjury, patronage, misrepresentation, nepotism, self-enrichment and even the topical "state capture" have become the order of the day, it would not be too surprising should similar negative influences also become prevalent in PHEIs. The research proposition that the ANC's BEE policy could have a potential financial influence or impact on PHEIs in South Africa should they need to become BEE compliant, should, in view of the findings of this research, therefore be accepted.

Again, given the findings of the research on which this article was based, the ANC should not try to enforce compliance to this racially inspired BEE policy in PHEIs. As in the past, the BEE policy has done little to bring about high economic growth $(-0.3 \%$ and $-0.7 \%$ GDP growth recorded during the first two quarters of 2017 (News24, 2017a)), to reduce unemployment (record 27.7\% rate in second quarter 2017 (News24, 2017b)), to eradicate the high levels of poverty (more than 50\% of all South Africans now living in poverty (Statistics SA, 2017)) and to narrow the ever-widening gap of inequality experienced in the country (these objectives are frequently cited as the government's top-priority drivers). Rather, it could be argued that BEE has nefariously aided efforts towards state capture (GuptaLeaks, 2017), which is accompanied by rampant corruption, cheating and collusion, and thus further has the potential to destroy another key pillar of a future South Africa, namely its education system. 


\section{REFERENCES}

1. Cohen, L., Manion, L., \& Morrison, K. (2005). Research methods in education (5th ed.). London, UK: Taylor and Francis e-Library.

2. Department of Higher Education and Training (2017a). Statistics on post-school education and training in South Africa: 2015. Pretoria, South Africa: Department of Higher Education and Training. Retrieved from http://www.dhet.gov.za/ DHET\%20Statistics\%20Publication/ Statistics\%20on\%20Post-School\%20 Education\%20and\%20Training\%20 in\%20South\%20Africa\%202015.pdf

3. Department of Higher Education and Training (2017b). Annual monitoring report on the compliance of private higher education institutions (PHEIs). Pretoria, South Africa: Department of Higher Education and Training. Retrieved from http://www.appetd.org.za/ wp-content/uploads/2017/11/2015Compliance-Report-for-PHEIs-1. pdf

4. Department of Trade and Industry. (2012). Economic empowerment. Retrieved from https://www.thedti. gov.za/economic_empowerment/ docs/bee_launch.pdf (accessed on August 21, 2017).

5. Department of Trade and Industry. (2016). Economic empowerment. Retrieved from http://www.dti.gov. za/economic_empowerment/bee. jsp (accessed on January 26, 2017).

6. Dirkse van Schalkwyk, R., \& Steenkamp, R. J. (2016). A top management perspective of total quality service dimensions for private higher education institutions in South Africa.Southern African Business Review, 20, 577-599. Retrieved from https://www. ajol.info/index.php/sabr/article/ view/151766

7. Fourie, M. (2009). Institutional governance in SA higher education: For the common good or political power play? In E. Bitzer (Ed.), Higher education in South Africa: A scholarly look behind the scenes. Stellenbosch, South Africa: SUN Media.

8. GuptaLeaks (2017). Why you should care about the Gupta leaks: An international view. Retrieved from http://www.gupta-leaks.com/atulgupta/why-you-should-care-aboutthe-guptaleaks-an-internationalview/ (accessed on August 24, 2017).

9. Jeffery, A. (2014). BEE: Helping or hurting? Cape Town, South Africa: Tafelberg.

10. Krüger, L. P. (2018). The impact of black economic empowerment (BEE) on the macro-environments of South Africa - time to stop the rot, deterioration, distrust and dysfunctionality. Problems and Perspectives in Management, 16(1), 361-380. http://dx.doi.org/10.21511/ ppm.16(1).2018.35

11. Leedy, P. D., \& Ormrod, J. E. (2015). Practical research: Planning and design (11th ed.). Harlow, UK: Pearson Education.

12. Levy, D. C. (2002). Commercial private higher education: South Africa as a stark example. Perspectives in Education, 20(4), 29-39. Retrieved from https:// journals.co.za/content/persed/20/1/ EJC87164

13. Mackenzie, N., \& Knipe, S. (2006). Research dilemmas: Paradigms, methods and methodology. Issues in Educational Research, 16, 1-10. Retrieved from http://www.iier.org. $\mathrm{au} /$ iier16/mackenzie.html

14. Marais, A. (2014, December 8). ' $n$ Matrieksertikaat is nie meer genoeg nie. Translated into English as "A senior certificate is no longer sufficient". Retrieved from http:// www.netwerk24.com/Nuus/ Onderwys/n-Matrieksertikaat-isnie-meer-genoeg-nie-20141208 (accessed on August 25, 2017).

15. Nel, C. (2015). Eerstejaars: UJ kry 111200 aansoeke, laat net 10500 toe. Translated into English as "First years: UJ receives 111200 applications, only accepts 10 500". Retrieved from http://www. netwerk24.com/Nuus/EerstejaarsUJ-kry-111-200-aansoeke-laat-net10-500-toe-20150108 (accessed on June 10, 2016).

16. News24 (2017a). SA: Drawing parallels between 1985 and now. Retrieved from http://www.fin24.
com/Economy/sa-drawingparralels-between-1985-andnow-20170814 (accessed on August 14, 2017).

17. News24 (2017b). Youth vulnerable as unemployment stays at highest rate since 2003. Retrieved from http://www.news24.com/Fin24/ youth-vulnerable-as-unemployment-stays-at-highest-ratesince-2003-20170807-3 (accessed on August 15, 2017).

18. Prominent People (2013). Presidents of South Africa. Retrieved from http://prominentpeople.co.za/presidents-of-south-africa.aspx (accessed on May 31, 2017).

19. Slack, N., Brandon-Jones, A., \& Johnston, R. (2013). Operations management (7th ed.). London, UK: Pearson.

20. Statistics SA (2017). More than 50 percent of SA's population is living in poverty. Retrieved from http:// www.fin24.com/Economy/morethan-50-of-sas-population-is-livingin-poverty-20170822 (accessed on August 22, 2017).

21. Vega School (2017). Lack of space at public universities needn't spell end of degree dreams. Retrieved from http://www.bizcommunity.com/Article/196/499/156419.html (accessed on February 15, 2017).

22. Visagie, R. (2012). Methodological rigour and ethics of accountability within a qualitative framework. Emoyeni Research Collaborations, 8-12.

23. Visagie, R. (2013). Choosing among the three paradigms. Emoyeni Research Collaborations, 19.

24. Washington Post (2013, December 5). Nelson Mandela's famous quote on education. Retrieved from https://www.washingtonpost.com/news/answer-sheet/ $\mathrm{wp} / 2013 / 12 / 05 /$ nelson-mandelasfamous-quote-on-education/?utm term $=.8 \mathrm{~d} 8587 \mathrm{f} 6 \mathrm{bc} 71$ (accessed on August 4, 2017).

25. Welman, C., Kruger, F., \& Mitchell, B. (2005). Research methodology (3rd ed.). Cape Town, South Africa: Oxford University Press. 